\title{
Negotiating Territorial Change in Multinational States: Party Preferences, Negotiating Power and the Role of the Negotiation Mode
}

\author{
Bettina Petersohn,* Nathalie Behnke, ${ }^{\dagger}$ and Eva Maria Rhode \\ *University of Edinburgh; b.petersohn a ed.ac.uk \\ †niversity of Konstanz \\ University of Konstanz
}

In this article, we offer an explanation for varying patterns of territorial reforms aimed at accom modating claims for more substate autonomy in multinational states. We argue that the interaction between preferences of state wide and non statewide parties, their negotiation power and the negotiation mode accounts for specific patterns of territorial change. Analytically, we advance existing research in two ways: First, by analyzing territorial change in a two dimensional space (vertical and horizontal), we pay explicit attention to jurisdictional heterogeneity between substates. Second, by applying an actor centered institutionalist approach, we highlight the stra tegic potential of actors within the institutional setting. The comparative analysis of thirteen processes of territorial change in four multinational Western democracies Canada, Belgium, Spain, and the UK reveals, first, certain conditional effects of the independent variables on specific patterns of territorial change and, second, how the negotiation mode impacts on a party's negotiation power.

In multinational states, changes in the allocation of power between levels of government typically result from (re-)negotiations of territorial power allocation between different cultural or national communities and the central state. The establishment or enlargement of a (quasi-)federal power distribution is often recommended as an appropriate and mutually acceptable response to demands for special recognition, protection, and autonomy by those communities (Amoretti and Bermeo 2004; Bermeo 2002). However, among multinational democracies, territorial changes, that is, changes in the territorial allocation of power, vary regarding the degree of autonomy, the type of power (administrative, legislative, or fiscal) transferred to substate nations or territories, the speed with which changes are effectuated and the territorial dynamics that result from those changes in the 
long run. In this article, we tackle the question how such varying results of territorial reform processes can come about. Existing federalism scholarship offers several explanations for territorial power distributions (for an overview see Gerber and Kollman 2004). In the tradition of constitutional design (Filippov, Ordeshook, and Shvetsova 2004; Bednar 2009), the inherent instability in federal architectures needs to be balanced by safeguarding institutions, thus curbing any attempt of either the center or the periphery to unduly expand their powers, change the allocation of power, or encroach into the jurisdiction of the other level of government. It follows from this that the institutional structure as set by the constitution also impacts on the way federal and substate governments interact with each other (Bolleyer, Swenden, and McEwen 2014). From a sociological perspective, the territorial power distribution follows socio-cultural patterns in the society, for example, the territorial concentration of linguistic or ethnic groups (Erk and Koning 2010). A clear mechanism how these patterns translate into institutional changes still needs to be developed. From a historical-institutionalist perspective, precedents and conventions (Broschek 2011) or path-dependent evolution can yield in distinctive ways in which territorial negotiations are conducted (Petersohn 2011). All those approaches, whether they rely on institutional design, or on group identity, however, overstate the role of those factors in determining changes to the territorial distribution of power. They neglect the strategic power of interested actors to use institutions or a sense of belonging purposefully to pursue their interest. Therefore, they are unable to account for different patterns of territorial change within one country. In taking the perspective of actor-centered institutionalism, we acknowledge the role of institutional settings in shaping actors' behavior. Still, actors have leeway in how they make use of opportunities offered by the institutions in which they operate. By focusing on the negotiation process itself-restricted by the institutional setting in which it takes place, but driven and shaped by interested actors-we are able to account for different patterns of territorial change within one country.

In this article, we refine existing concepts for analyzing territorial change in two ways: First, we develop a two-dimensional concept of territorial power change. Such change has generally been addressed in terms of (vertical) decentralization (Montero 2005; Treisman 2007), but we include and refine a second dimension of (horizontal) (a-)symmetry, which has been found to be relevant in the Spanish and British cases (Lecours 2004; Colino 2008; Hombrado 2011). Apart from asymmetric solutions agreed upon in the initial decentralization reform, jurisdictional asymmetry can be increased if more than two levels of competences are introduced in later processes of territorial change. With such a refined concept of asymmetry that accounts for intermediate positions between the least and most empowered entities, we are able to describe and classify territorial change, thus contributing to 
a better understanding of the consequences of accommodating demands for decentralization in multinational contexts.

Second, in analyzing the preferences and negotiation power of territorial actors, we apply an actor-centered perspective to the analysis of processes of territorial power change. We regard parties as the main drivers in negotiations on territorial change, where they try to realize their preferences in a given institutional setting. Scholars of territorial party politics (TPP) shed light on parties as entrepreneurs of territorial change, analyzing their strategic positioning in light of electoral threat from regionalist parties or the position of main statewide competitors as well as their reactions to territorial change (Swenden and Maddens 2009a; Meguid 2005, Toubeau and Wagner 2015). Also, TPP research produced considerable evidence on party preferences and positions with regard to territorial issues (De Winter, Gómez-Reino, and Lynch 2006; Massetti and Schakel 2013a) and accounted for the increasingly multilevel character of party politics (Toubeau and Massetti 2013; Detterbeck 2012; Swenden and Maddens 2009b). But so far, we lack a theoretical model of the relationship between party preferences, negotiations, and shifts in the territorial power allocation. In our article, we fill this gap and complement existing TPP research by explicitly taking into account not only party preferences, but also how the negotiation setting influences actors' chances to pursue their preferences. We assume that the chances for a party to realize its preferences depend not only on its electoral and legislative power, but also on the negotiation mode, which can be unilateral, bilateral, or multilateral. The central argument in our article is that party preferences and parties' negotiation power interact with the negotiation mode, thus influencing the resulting territorial change on the vertical as well as the horizontal dimension.

The article is structured as follows: First, we develop our analytic framework. We operationalize the relevant variables-territorial change as the outcome variable, the parties' negotiation power and the negotiation mode as independent variables and the parties' territorial preferences as the given conditions based on which the negotiation process is initiated. Then, we explain our design, rationale of case selection and sources of data used. Next, we present afterwards empirical evidence from the reform processes under scrutiny, structuring the comparison along specific patterns of territorial change. Finally, we synthesize the lessons from this comparison, elaborating in greater detail the effects of party preferences, negotiation power, and negotiation mode on territorial change and-in the long run—on territorial dynamics.

\section{Analytic Framework}

We assume that territorial changes are a function of renegotiations of the territorial power allocation among interested actors. In developing our argument, we employ the analytic perspective of actor-centered institutionalism (Scharpf 1997), which 


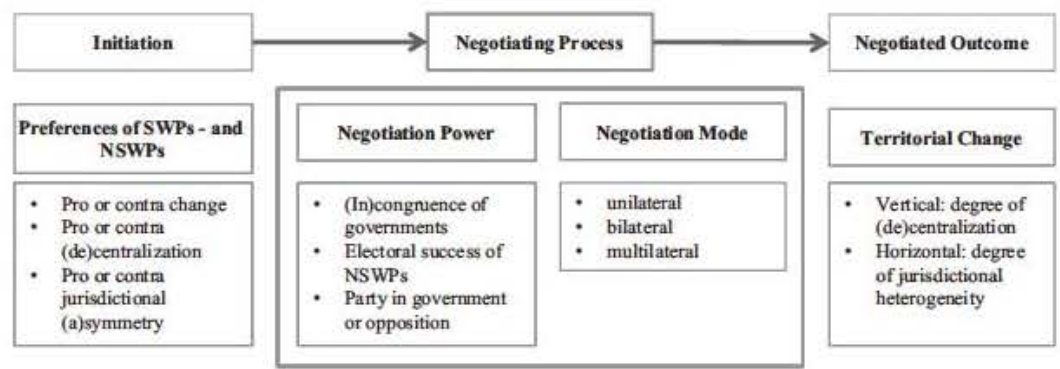

Figure 1 Analytic framework.

regards actors interested in change as the main drivers for institutional reform; the strategic opportunities of these actors are shaped by the institutional setting in which they operate. Our analytic model (as presented in figure 1) essentially consists of three elements. First, actors hold preferences toward territorial change and will act accordingly. In our case, the most influential actors are political parties that will either try to promote or to block initiatives for territorial reform. We ascribe preferences regarding territorial change to parties depending on whether they are a statewide party (SWP) or a non-statewide party (NSWP). Second, the chance for a party to realize its preference depends on situational factors and institutional settings of the negotiation process: The negotiation power is defined by the relative electoral strength of a party; the existence or nonexistence of party congruence at federal and substate levels; and by a party's status as member of a governing coalition or opposition. The negotiation mode defines the constellation of actors involved in negotiations and whose consent is necessary for reaching an agreement. It can take the form of uni-, bi-, or multilateral negotiations. The power each party has in negotiation processes is, therefore, defined in relation to other parties and potential competitors at both levels as well as by the institutional setting of the process. Third, reform attempts may result in different patterns of territorial change on the vertical and/or horizontal dimension of power allocation.

\section{Territorial Change}

We define territorial change as an alteration in the allocation of power between different levels of government. For our purpose, we focus on changes of constitutional or equivalent provisions resulting from formal negotiations. Changes in the territorial power allocation can take place along two dimensions, vertical or horizontal, altering either the relationship between the central level and substates or among different substates. On the vertical dimension, the degree of (de)centralization determines the autonomy or self-rule that central and substate governments enjoy. An increase in decentralization results from a power transfer from the center 
to substate governments. In contrast, decentralization can be reduced by shifting power from the substates to the central level, thereby reducing the autonomy of substate actors. In focusing only on the self-rule component of substate power, we deliberately neglect the shared rule component (Elazar 1987) to get a clear definition of the competences allocated to a level of government. ${ }^{1}$

On the horizontal dimension, we compare the power and resources of substate entities in relation to each other. Symmetry exists when all entities enjoy the same level of power and responsibilities; in contrast, under asymmetric arrangements, the level and scope of legislative, administrative, or fiscal autonomy can differ significantly among the substates. De facto asymmetries refer to differences in population, geographic or economic conditions which always exist and are not subject to institutional design. De jure asymmetries, in contrast, are caused by differential jurisdictional endowments and are the only meaningful category for comparing substates' competence levels. We hence focus on de jure asymmetries in our analysis (for the distinction see Watts 1999).

We introduce the term "jurisdictional asymmetry" to capture the number of competence levels that substate units hold and the distances between these levels compared to a symmetrical allocation of power to all substates. An increase in jurisdictional asymmetry would be the result of a reform in which the most empowered substate receives more competences and/or the least empowered substate loses competences. Conversely, the overall jurisdictional asymmetry will be decreased if the most empowered substate loses competences and/or less empowered substates obtain more competences thereby reducing the distance between the competence levels. If more intermediate competence levels are established by transferring power to substates that do not reach the level of the most empowered substate, jurisdictional asymmetry is increased as well. If these substates catch up with the higher power level in later reforms, we treat this change as reduction of asymmetry because the number of competence levels is reduced again and more substates are treated equally.

Based on those distinctions, territorial change may affect the degree of (de)centralization along the vertical dimension and/ or the degree of jurisdictional asymmetry along the horizontal dimension. ${ }^{2}$ A maximum of decentralization is reached when the central level retains only minimal competences (mostly defense and taxation, which can be shared as well). A maximum of jurisdictional asymmetry would be reached if each substate has a different competence level and the distance between the lowest and the highest competence level is maximized.

\section{Party Preferences and Territorial Change}

Parties at the central and substate levels are the most important actors involved in negotiating territorial change. For the purpose of our analysis, we follow Scharpf's 
account of actor-centered institutionalism, treating parties as complex actors, able to act strategically based on their internal processes of preference formation, without, however, analyzing those internal processes (Scharpf 2000, pp. 95-110). Rather, we ascribe typical preferences regarding territorial change to different types of parties. For the purpose of our analysis it does not matter whether those preferences are "genuine" or strategic. It suffices that a party plausibly holds this preference and can be expected to act accordingly. In multinational states, the cultural diversity of territorially concentrated groups promotes the emergence of NSWPs $^{3}$ campaigning in only one or a few substates. Only in rare instances do NSWPs campaign successfully at the central level. Decentralization may empower NSWPs at the regional level and yield in gains in subsequent elections (Massetti and Schakel 2013b, pp. 815-16). It is therefore particularly rational for a NSWP to prefer an increase in regional autonomy if their chances of governing the region or gaining electoral strength are high. SWPs, in contrast, campaign at both levels of government and across regions and generally try to integrate large sections of society. They typically represent preferences in favor of a strong central level and against further decentralization. Due to their appeal to all regions, SWPs at the central level will also have a preference for symmetric power distributions. They may, however, promote further decentralization as a strategy to distance themselves ideologically from their main competitor at the central level (Toubeau and Wagner 2015, p. 110). Preferences of SWPs may become less clear when we include the party competition in the substates. When strong at the regional level and weaker at the central level, SWPs are more likely to advocate decentralization. Regional branches of SWPs may be inclined to strategically opt for an increase in decentralization when threatened by an NSWP to prevent the loss of votes in that particular substate or, if the economic position of the NSWP is similar to that of the SWP (Toubeau and Massetti 2013, Maddens and Libbrecht 2009, Meguid 2005, Sorens 2009, Toubeau and Wagner 2015). In those cases, SWPs face stronger internal frictions challenging their overall preference for a symmetric power allocation.

\section{Institutional Setting of the Negotiation Process}

Negotiation power

The chances of a party to realize its preferences with regard to territorial change depend mainly on its negotiation power. In accordance with recent studies in the field of TPP in multilevel systems (Detterbeck 2012, Swenden and Maddens 2009a), we distinguish three sources of negotiation power. First, a party's strength in the electoral and parliamentary arena based on vote and seat shares reflects its chances of influencing political results, either directly through participation in government or indirectly by posing an electoral threat to the governing parties. Second, when a 
party is in government or is a member of the governing coalition, its opportunities to bargain for territorial change are better than when it is in opposition. Although being in government offers a direct opportunity to influence decisions, opposition parties are strengthened in situations of minority government or constitutional change, where issue-specific coalitions or higher thresholds of consent may effectively endow them with a veto position. Third, congruence or incongruence in governing coalitions across the levels of government has an impact on a party's negotiating power (Elias and Tronconi 2011, pp. 518-20). Congruence increases the number of access points to decision-making and offers the opportunity to coordinate strategies across levels of government, thereby enhancing the chances of enacting or preventing a reform.

\section{Negotiation Mode}

The negotiation mode shapes how a party's preferences translate into reform results. Based on the involvement of government levels, we distinguish three modes: unilateral negotiations involve only actors at the center (executive or parliamentarian); bilateral negotiations are conducted between the center and one substate entity; and in multilateral negotiations, the center and representatives of most or all substate entities participate. ${ }^{4}$ Depending on the negotiation mode, actors' constellations vary. Which mode is applied in a negotiation situation is an empirical question.

In a unilateral mode, only party strength and government involvement as aspects of a party's negotiation power matter; as only one level is involved, congruence is irrelevant. In a bilateral mode, all aspects of negotiation power can be relevant. As only one substate unit is involved, an increase in jurisdictional asymmetry is a likely result of initial decentralization reforms. Multilateral negotiations require a consensus among diverging interests of representatives from the center and substates. In such a setting, particularistic demands must be moderated, connected to arguments acceptable to larger segments of the society, or included in package deals (Elster 1998). There, incongruence is the most likely case, as it is highly improbable that among all units involved the same coalition government rules. Party strength and government involvement matter insofar as the party which initiates the reform has better chances to successfully pursue its preferences, the stronger it is across substates. Finally, in a multilateral negotiation setting, the need to consider all sides will encourage symmetric solutions.

\section{Design and Case Selection}

Since it is the aim of this article to explain variation in patterns of territorial change, we compare reform processes in Western democracies according to their variation on the dependent variable. That is, we classify reform outcomes along the 
vertical and horizontal dimensions of territorial change, inferring the directions of change from an analysis of reform documents. If, for example, a reformed statute of autonomy or a reformed list of legislative competences of a substate unit contains more competences than before the reform, then we have a clear indication of a territorial change on the vertical, and possibly on the horizontal, dimension. ${ }^{5}$ We then characterize the reform processes according to the preferences of the initiating party/parties, their negotiation power and the negotiation mode involved. The empirical classifications are based on original fieldwork, interviews, and analysis of parliamentary and party documents. By systematically comparing the patterns of preferences, process variables and outcomes, we are able to analyze the interaction of negotiation power and negotiation mode in shaping territorial change.

The reform cases under scrutiny were selected in two steps. In a first step, we picked the four "classic" cases of multinational democracies: Canada, Belgium, Spain, and the UK (Gagnon and Tully 2001; Keating 2001). All four of these countries have extensive experience in accommodating demands for greater autonomy from territorially concentrated national minorities. In terms of the dependent variable, they have all undergone significant changes in their territorial power distribution in recent decades; however, with differences regarding the two dimensions. Though in Spain and the UK, powers were decentralized allowing for asymmetries between the substates, symmetry was largely kept in the Belgian transformation into a federal state. Canadian federalism was challenged by similar demands for special recognition of Quebec that aimed at an asymmetrical increase in power for that province. In comparison, NSWPs exist in all those substates of our four states that contain a distinct group. Their electoral success posed a threat to governing SWPs in certain elections and increased the pressure for territorial change. As we can identify differences in the reform outcomes, however, the electoral strength of NSWPs cannot in itself explain the negotiated change of territorial power allocation. In the second step, we selected the reform processes in the four countries that

- were triggered by one or several interested parties to which the initiation of the process can be clearly attributed

- and sought to reform of the existing allocation of power

- by setting in motion a negotiation process, possibly through parliamentary acts or constitutional reforms, irrespective of the success or failure of ratification.

We chose reforms that aimed to change the division of power in an already existing multilevel context to study interactions between party politics and territorial change. The existence of regional elections forms a scope condition for case selection, so that the initial decentralization reforms were not included in the analysis as they served to establish the substates and the multilevel setting 
(Bezes and Parrado 2013, p. 26). Based on these criteria, we identified thirteen reforms in the four countries. When a reform process contained different phases with changes in involved negotiating actors we treated the phases as different cases to trace the interaction between negotiation power and negotiation mode. Technically, we therefore analyze fifteen cases made up of thirteen reforms. In Spain, nearly all autonomous regions have reformed their statutes of autonomy over the last three decades. However, they basically follow two typical patterns of territorial change. Decentralization "vanguards" took the initiative in bilateral negotiations thereby increasing asymmetric decentralization, while "less empowered" substates have attempted to catch up with the higher levels of autonomy (Hombrado 2011). We selected the Catalan Statute Reform of 2006 (nationalitybased unit, vanguard region) and the Andalusian Statute Reform of 2006 and its referendum in 2007 (regionally based unit, initially less empowered substate) as representative cases of each group. ${ }^{6}$ The Plan Ibarettxe in the Basque Country could also represent the dynamic initiated in a vanguard region. However, it was blocked at the central government level and displays a distinct pattern and thus deserves to be considered on its own (see table 1 for an overview of the cases).

\section{Patterns of Territorial Change}

Based on our two-dimensional conceptualization of territorial change, we can theoretically distinguish nine different patterns. They result from the combination of an increase $(+)$, a decrease $(-)$, or no change $(0)$ in the degrees of decentralization (vertical dimension) and of jurisdictional asymmetry (horizontal dimension). Of those nine possible patterns, however, only four appear empirically in our sample. Three are logically not feasible or highly implausible, and two, although possible in theory, have no empirical manifestation (table 1).

In the following subsections, we describe the observed patterns (patterns 1, 2, 3, and 5) according to the relevant variables identified above, thus revealing distinct configurations of preferences, negotiation power, negotiation mode, and territorial change.

\section{More Asymmetry and More Decentralization-No. 1: The Distancing Pattern}

We found two instances of this pattern, in which competences were transferred to the most empowered region only, thus simultaneously resulting in greater decentralization and increased jurisdictional asymmetry. The pattern was found in Spain and the UK, each in connection with a bilateral negotiation mode. In both cases, radical claims for more (and asymmetric) regional autonomy put forward by nationalist NSWPs (with or without the participation of regional governments) coincided with moderately decentralization-friendly attitudes of SWPs governing at the center. 
Table 1 Patterns of territorial change and their empirical manifestation

\begin{tabular}{|c|c|c|c|}
\hline $\begin{array}{l}\text { Asymmetry } \\
\text { decentralization }\end{array}$ & + & 0 & \\
\hline+ & $\begin{array}{l}\text { Pattern no. 1: } \\
\text { - ESP: Catalan Statute } \\
\text { Reform } 2006 \\
\text { (bilateral) } \\
\text { - UK: Scotland Act } \\
2012 \text { (bilateral) }\end{array}$ & $\begin{array}{l}\text { Pattern no. 2: } \\
\text { - BEL: Const. revision } \\
1993 \text { (unilateral) } \\
\text { - BEL: State reform } \\
2001 \text { (unilateral) } \\
\text { - CAN: Constitution } \\
\text { Act } 1982 \\
\text { (multilateral) } \\
\text { - CAN: Meech Lake I } \\
1987 \text { (multilateral) } \\
\text { - CAN: Charlottetown } \\
\text { I } 1992 \text { (multilateral) }\end{array}$ & $\begin{array}{l}\text { Pattern no. 3: } \\
\text { - ESP Autonomous } \\
\text { Agreement } 1992 \\
\text { (unilateral) } \\
\text { - BEL: State reform } \\
2012 \text { / } 2013 \\
\text { (unilateral) } \\
\text { - ESP: Andalusian } \\
\text { Statute Reform } 2007 \\
\text { (bilateral) } \\
\text { - UK: Government of } \\
\text { Wales Act } 2006 \\
\text { (bilateral) } \\
\text { - UK: Referendum } \\
\text { on primary } \\
\text { powers for Welsh } \\
\text { Assembly } 2011 \\
\text { (bilateral) }\end{array}$ \\
\hline 0 & $\begin{array}{l}\text { Pattern no. } 4: \\
\text { logically impossible }\end{array}$ & $\begin{array}{l}\text { Pattern no. 5: } \\
\text { - ESP: Plan Ibarretxe } \\
2005 \text { (bilateral) } \\
\text { - CAN: Meech Lake II } \\
1990 \text { (ratification } \\
\text { failure) } \\
\text { - CAN: Charlottetown } \\
\text { II } 1992 \text { (ratification } \\
\text { failure) }\end{array}$ & $\begin{array}{l}\text { Pattern no. } 6 \text { : } \\
\text { logically impossible }\end{array}$ \\
\hline - & $\begin{array}{l}\text { Pattern no. } 7 \\
\text { logically implausible }\end{array}$ & $\begin{array}{l}\text { Pattern no. 8: } \\
\text { no empirical } \\
\text { evidence }\end{array}$ & $\begin{array}{l}\text { Pattern no. 9: } \\
\text { no empirical } \\
\text { evidence }\end{array}$ \\
\hline
\end{tabular}

In Spain, the Catalan Statute Reform of 2006, ${ }^{7}$ part of the second wave of reforms of the statutes of autonomous communities (ACs), extended the region's autonomous powers considerably in comparison to the other autonomous communities (ACs) at this point in time-in many different areas like public administration, commerce and trade fairs, consumption and promotion, health 
care, education, media and language rights. The reform was initiated by the Catalan Socialist Party Partit dels Socialistes de Catalunya (PSC), the strongest party in the Catalan government, which preferred moderate decentralization. In elaborating the reform at regional level, the PSC included nationalist parties in the negotiation process. It formed a coalition government (Tripartito Catalán) with the strongly nationalist Esquerra Republicana de Catalunya (ERC) and the green party group Iniciativa per Catalunya Verds-Esquerra Unida i Alternativa (ICV-EUiA), and it also needed the support of the moderately nationalist Catalan NSWP CiU as the main opposition party to achieve the required two-thirds majority to approve the reform proposal in the Catalan Parliament. Both NWSP's, the more moderately nationalist Convergència I Unió (CiU) (from its opposition position) and the ERC (as coalition partner), were able to pressure the PSC to formulate more radical demands for asymmetric decentralization. Congruence between the levels was partial with a minority government led by the Partido Socialista Obrero Español (PSOE) in Madrid (beginning in 2004), and also with the ERC which supported the PSOE-led minority government at national level. Thus Socialist congruence tended to moderate the Catalan demands toward symmetry, while the influence of the ERC tended to radicalize them toward asymmetry. An agreement was finally reached, and the reform statute was adopted first in the Catalan parliament by all parties except the Partido Popular (PP) and then in the national parliament with the opposition of the PP and the ERC. Ultimately, the new statute was accepted by referendum.

The Scotland Act of $2012^{8}$ provided for a substantive extension of the powers of the Scottish government, primarily in taxation and fiscal policy. It was a direct consequence of the establishment and report of the "Calman Commission" (McLean, Gallagher, and Lodge 2013, 61-64). The Calman Commission was set up in 2008 with the support of the majority opposition in the Scottish Parliament (Scottish Labour Party (SLP), Scottish Liberal Democrats (SLibDem), and Scottish Conservatives) to counter the motion of the Scottish National Party (SNP) minority government for a "National Conversation" on an independence referendum. Thus, the initiative for extended devolution came from an opposition coalition of anti-nationalist SWPs as a clear reaction to the electoral-and legislative-threat posed by the governing SNP and its independence movement. Governments in London and Edinburgh were incongruent, but the Labour government in London could rely on the "coalition" of opposition parties SLP, SLibDems, and Scottish Conservatives that had initiated the reform in Scotland. The subsequent legislative process lasted three years, during which government majorities changed. In Westminster, the general elections in 2010 brought a Conservative government into power, while the Scottish parliamentary elections elevated the SNP from a minority to a single-party majority government. Hence, there was complete incongruence of governments in 2012, when the Act was finally 
passed by both parliaments with the consent of the SNP (after several amendments had been made upon its suggestion).

More Decentralization, but No Change in Asymmetry-No. 2: Consensual Power Transfer

A symmetric increase in decentralization resulted from uni- and from multilateral negotiations in five instances of our sample. NSWP played a role in the trend toward greater decentralization in Belgium and Canada, threatening the electoral success of established parties but without necessarily participating in the negotiations. Characteristic of these cases was a consensus between either the two levels of government or between the conflicting groups at the central level. The consensual style prevented the diverging preferences of negotiating actors from translating into an asymmetric power arrangement.

\section{Unilateral negotiations}

The constitutional revision 1993 in Belgium resulted in the federalization of the country. Together with the state reform of 2001 the level of decentralization was further increased and the regions received some degree of fiscal autonomy. In 1993, negotiations resulted in a compromise that deferred to demands for greater autonomy from the Flemish parties as well as to demands for more financial transfers from the Francophone parties (Clement et al. 1994, p. 27-29; Lentzen and Blaise 1993$)^{9}$. In 2001, the final compromise ${ }^{10}$ included a symmetric increase in both legislative power and financial resources for all Communities and Regions (Delwit and Hellings 2002; Jacques and Boromée 2001).

In both processes, negotiations took place between parties of the governing coalitions at the federal level without the explicit inclusion of representatives of regional governments or parliaments. ${ }^{11}$ The governing coalition at the federal level (in 1993, formed by Christian Democrats and Socialists from both linguistic sides; in 2001, by Liberals, Socialists, and Ecologists from both linguistic sides) initiated the reforms but persistently lacked the two-thirds majority required for successful ratification. Negotiations between the governing parties were, therefore, bipolar and had an intergroup aspect without being bilateral according to our definition. Opposition parties, especially the Flemish nationalist Volksunie ${ }^{12}$ became pivotal in reaching the threshold and held strong negotiation power in spite of its declining electoral success. In this position, the party was able to push for more autonomy in exchange for their support. In 2001, the Volksunie again bargained for a greater transfer of fiscal powers to the regions. Due to internal divisions within the VU and the defection of four of their eight parliamentarians, the governing parties had to turn to another opposition party. That time, the Francophone Christian Democrats helped to reach the two-thirds majority by abstaining from the vote. In exchange, they demanded an increase of financial transfers to the Communities as the 
Francophone Community was notoriously running into debts. Opposition parties from both linguistic sides held strong negotiation power and were driving the negotiations. Due to the consensual and unilateral negotiation mode, however, the final result was symmetric despite differences in preferences held by the parties of the two linguistic sides.

\section{Multilateral negotiations}

The three cases of multilateral negotiations in Canada were the Constitution Act 1982, the Meech Lake process and the first phase of the process leading to the Charlottetown Accord in 1992. The demand for greater recognition of Québec's distinct character, a further increase in provincial autonomy, and the reduction of federal encroachment into provincial jurisdiction were on the agenda of all three negotiation processes. The low vertical integration of parties in Canada also meant that incongruence in governing parties did not play an important role in any of the negotiations of territorial change.

The Constitution Act 1982 included a symmetrical increase in provincial autonomy together with the introduction of an amendment formula and the Charter of Rights and Freedoms. Negotiations leading to the final agreement were based on federal initiative and followed the pattern of "federal-provincial diplomacy" characteristic of Canadian federalism (Simeon 1972) between the Liberal Prime Minister and the provincial Premiers, thereby reducing the influence of legislative assemblies and opposition parties. Québec's demands for a general veto in constitutional reforms and for recognition of its distinctiveness went beyond the preferences of the other provincial premiers, but the majority of them were ready to bargain for greater provincial autonomy. Pressures from a NSWP were strong, as the separatist Parti Québécois (PQ) had won the provincial elections in 1976 with the promise of holding a referendum on secession within the legislative term. The Constitution Act 1982 reflected a package deal between the federal government's interest in adopting an amendment formula and a Charter of Rights, as well as provincial preferences for increased autonomy. However, the distinct demands of Québec for a veto and special recognition were not included in the horizontally symmetric result (Laforest 1991). Even a separatist government in Québec was not sufficient to produce an asymmetric outcome in the multilateral setting.

Negotiations leading to the Meech Lake Accord of 1987 were initiated by the Conservative federal government under Brian Mulroney with the aim of reintegrating Québec into the constitution. After initial bilateral talks between the liberal government in Québec and the federal government, negotiations were conducted multilaterally including all provincial premiers and the federal government. Demands from Québec focused on the recognition of Québec as a "distinct society," a veto over future constitutional reform, limits to the federal spending power and a guarantee of three Supreme Court judges selected from the 
Quebec bar. Pressure from the nationalist PQ was low, as the PQ had just lost the elections. The incongruence between the levels was of limited relevance, as Québec's provincial parties are characterized as "truncated," with high degree of independence from the central parties (Thorlakson 2009). Being in government at the federal level, the Conservative leadership and the intention to appease Québec to bring the province back into the federation were major factors for consenting to an increase in provincial powers as a result of the negotiations (Cairns 1988, pp. 112-13). As negotiations followed predominantly a multilateral mode, offers that had been made to Québec at the beginning were eventually extended to other provinces resulting in an agreement ${ }^{13}$ that would have symmetrically increased the power of all provinces alike, had it been successfully ratified (Milne 1988).

Immediately after the failed ratification of the Meech Lake Accord, negotiations were again initiated by the federal government under Conservative Brian Mulroney, eventually leading to the Charlottetown Accord in August 1992. In addition to delegates from the federal government and the provinces, representatives of First Nations organizations and the Territories participated in the multilateral negotiations. The result was a complex reform package that did include an increase in provincial power and recognition of the rights of First Nations, but again no special status or veto for Québec and, therefore, no significant jurisdictional asymmetries between the provinces (Russell 2004, pp. 171-89; Whitaker 1993). The recognition of the French presence in Canada did not explicitly focus on Québec, but included Francophone minorities outside the province. ${ }^{14}$ The electoral threat of the PQ was greater as the Québec Liberal Party (QLP) remained in office after the 1989 provincial elections but lost votes to the $\mathrm{PQ}$, thereby coming under increased pressure to negotiate a better deal for the province. The QLP, however, was not able so successfully translate that pressure into asymmetric concessions to Quebec during the multilateral negotiations.

\section{Re-symmetrization and More Decentralization-No. 3: The Catching-up Pattern}

This "catching-up" pattern, as we term it, results from initiatives of less empowered substate units to reach the same competence level as the most empowered substate units, thereby reestablishing a symmetric power distribution between them. ${ }^{15}$ By extending competences that had been granted to one or a few substate entities to some or all others, the catching-up pattern leads to a decrease in jurisdictional heterogeneity while the transfer of more competences includes an overall increase in decentralization. We observed this pattern in five cases from Spain, Belgium ${ }^{16}$ and the UK, involving uni- as well as bilateral negotiations.

\section{Unilateral negotiations}

The Autonomous Agreement of $1992^{17}$ was initiated by the central government in Spain to regain control over the irregular decentralization process that had 
produced many asymmetries between the ACs. The two main parties at the central level-the PSOE and the PP (as the most powerful opposition party)-agreed to upgrade the competences of the ten remaining ACs to reestablish symmetry among the Spanish substates ("equalization from above"). With the two major parties acting in concert (the PSOE holding 175 and the PP 107 of 350 seats), their joint negotiation power was so strong that the NSWPs in the national parliamentCatalonia's CiU and the Partido Nacionalista Vasco (PNV) from the Basque Country-tried in vain to pressure the SWPs into entering new bilateral negotiations with the ACs after the harmonization agreement had been signed.

In comparison, the state reform of 2012/13 in Belgium followed the same principle of negotiations between parties at the center as in previous reforms. While the reform of July 2012 focused on the community conflict and included the split of the electoral district of Brussels-Halle-Vilvoorde (BHV), the reform of December 2013 included a reform of the Senate and more fiscal autonomy for the regions. The asymmetries established during the early decentralization reforms between the smaller entities (German Community, Region of Brussels-Capital) and their larger counterparts (Flemish and Francophone Communities, Walloon Region and Flanders) were also abolished. ${ }^{18}$ With the reform of 2013, the German Community and the Region of Brussels-Capital received constitutional autonomy resulting in a symmetric distribution of power. For the initiation of the process, the success of the Nieuw-Vlaamse Alliantie (N-VA) in the federal elections of June 2010 was vital, as the party won the majority of Flemish seats and made an agreement on the enduring conflict over the electoral district of BHV and further fiscal autonomy for regions their priority. Only with that agreement, a government could eventually be formed in November 2011. The basics of the reform were included in the coalition agreement formed between six parties $^{19}$-Flemish and Francophone Socialists, Liberals and Christian Democrats - with the details elaborated afterwards in the parliamentary process.

\section{Bilateral negotiations}

The bilateral negotiation mode was found in Spain and the UK. The process of the Andalusian Statute Reform ${ }^{20}$ (2004-2007) was part of the second wave of statute reforms, targeted at enlarging the region's policy competences, especially in health and social welfare. The reform was initiated and promoted by the regional branch of the socialist party (PSOE-A), which had governed in Andalusia without interruption since 1982 and was in a government coalition with the nationalist NSWP Partido Andalucista (PA) at the time. The PSOE-A demanded a moderate and equalizing form of decentralization. The PA was in a weak position to promote stronger claims for autonomy, as the PSOE-A had successfully campaigned on a regionalist pro-Andalusian platform and already occupied that position (Cabeza and Gomez Fortes 2010, pp. 16-17). At the central level, the PSOE was in a 
minority government, thus securing congruence between the governments at both levels. As a result of the negotiations, Andalusia was able to catch up with the level of autonomy of Catalonia. Congruence between the regions of Andalusia and Catalonia facilitated this process of assimilation.

The second Government of Wales $A c t^{21}$ extended the powers of the Welsh Assembly and created a formal government, thus clearly separating the legislative and executive branches. Furthermore, it provided for a popular referendum in case the legislative powers of the Assembly were to be extended. Politically, it was the consequence of a report issued by the Richard Commission in 2004 (Bradbury and Mitchell 2005, p. 293) which had been established by the Welsh government as a concession to the pressure of the Welsh Liberal Democrats (WLibDems) in the coalition negotiations with the Welsh Labour Party (WLP). At that time, the WLibDems had a clear agenda of extending the autonomous powers of Wales, acting more like an NSWP than an SWP. The WLP, in contrast, was split on the issue, willing to promote devolution, but at a slow pace. Thus, in 2006, although then the WLP governed alone, the Welsh First Minister Rhodri Morgan was under pressure from several sides. The party's "own" report had recommended farreaching reforms, and the two opposition parties (WLibDems and the nationalist NSWP Plaid Cymru) represented a serious electoral threat to the tiny Labour majority. In this constellation, the WLP acted pro-devolutionist, thus becomingsomewhat contre-coeur-the driving force of the reform process (Wyn Jones and Scully 2012, p. 21). In close cooperation and complete congruence with the UK government (Trench 2008, p. 24), the bill was drafted, and the Act was passed by the UK parliament in 2006. It came into effect after the Welsh elections in 2007.

The Welsh Referendum of $2011^{22}$ was in a way the logical consequence of the Government of Wales Act of 2006. It was the final step on the path to establishing the Welsh Assembly as a fully-fledged parliament with genuine legislative powers in the devolved policy areas. The referendum had its roots in the 2007 coalition agreement between the WLP and Plaid Cymru after Plaid had won 15 of 60 Assembly seats, thus ending the WLP's single-party government and replacing it with a coalition between the more established SWP and a clearly nationalist NSWP. Under pressure from Plaid, the WLP agreed to commit itself far more strongly to devolution than it had originally intended (Wyn Jones and Scully 2012, p. 78). Although it had been initiated in a situation of partial party congruence with Westminster, the referendum was held after the Conservatives had won the general elections in 2010. However, this fact did not impede the process in any way. The referendum was held on November 3, 2011, with a 63.5 percent majority of "yes" votes, thus effectively reducing the region's asymmetry in comparison with Scotland.

As can be seen, bilateral negotiations result in a catching-up pattern when parties in less empowered substates negotiate with the center to close the gap with respect to other-vanguard-regions. Here, SWPs and NSWPs have concordant 
preferences, but when they have bargaining potential, NSWPs can push the reform further than intended by SWPs. Unilateral decisions by the central government are used to reduce jurisdictional asymmetries between the substates. When it is not possible to achieve it through recentralization, SWPs tend to accept a moderate increase in decentralization to obtain a more symmetric allocation of power.

\section{Attempted Change with No Reform-No. 5: The Blocked Pattern}

What we term a "blocked" pattern is a case of initiated negotiations that result in first or even final agreements but are not translated into a successfully ratified reform. We found three instances of this pattern in Spain and Canada, where failure of ratification was due to agents who were not at the negotiation table refuse to formally approve or ratify the reform package. In Canada, blocking occurred during the ratification phase after the main negotiations had been concluded.

\section{Bilateral negotiations}

The proposal for a new statute for Euskadi, the so-called Plan Ibarretxe was blocked in the second stage of negotiations by the conservative PP and the socialist PSOE in Spain's central parliament in 2005. Initiated in fall 2003 by the Basque government under Juan José Ibarretxe, the proposed reform was targeted at self-determination and a loose association between Spain and the Basque Country. At this time, the PP was still in power at the center, but the party later lost the 2004 election to a minority government of the PSOE under Jose Zapatero, supported by the Catalan ERC. As the Basque governing coalition consisted of three NSWPs (PNV, Eusko Alkartasuna - EA, and Ezker Batua-Berdeak - EB-B, of which the PNV and the EA were clearly nationalist), government coalitions were completely incongruent throughout the entire negotiation process. While the proposal did pass the Basque parliament with the votes of the majority parties, the PSOE and the PP rejected the proposal in both the regional vote and the central parliament. Threats from the ERC to withdraw its parliamentary support if Zapatero did not support the negotiation of the Basque reform proposal proved to be fruitless. ${ }^{23}$ Politically, the Plan Ibarretxe inspired another wave of statute reforms (Grau 2011, p. 188). The comparison with reforms of the Catalan and Andalusian statutes of autonomy initiated shortly thereafter demonstrates the relevance of at least partial congruence of governing coalitions for the success of bilateral negotiation processes.

\section{Multilevel ratification}

In Canada, the Meech Lake Accord of 1987 and the Charlottetown Accord of 1992 were the result of a compromise between representatives of the federal government and all provinces. Although it passed the vote in Parliament as well as in eight of ten legislative assemblies, the Meech Lake Accord failed to be approved by two provincial parliaments within the three-year ratification period. During these three 
years, provincial elections had changed the composition of provincial governments. As ratification spanned across the levels, a renewed consensus was required but could not be reached under the changed constellation of actors. Bilateral meetings were held between the federal Prime Minister and provincial premiers of New Brunswick, Newfoundland, and Manitoba but only New Brunswick ratified the Accord within the required period. However, the blocking of this reform was accompanied by the immediate initiation of a new round of negotiations (as described above). Two years later, in 1992, the successfully negotiated Charlottetown Accord eventually died in a popular referendum. The "no"-side of the referendum campaign was led by several nongovernmental organizations, but the PQ also campaigned against the Accord because the recognition of Québec's distinct character did not go far enough in their opinion (Russell 2004, p. 228). In both cases, the difference between negotiating and ratifying actors played a more important role for the final outcome of blocked reform than party congruence or negotiation power.

\section{Explaining Patterns of Territorial Change}

In this final chapter, we turn back from patterns to variables, analyzing their effects across the cases and patterns investigated. We try to infer from our limited empirical universe generalizable relationships between the dependent variableterritorial change-and the independent variables-negotiation power and negotiation mode.

In terms of the dependent variable, we distinguished vertical and horizontal territorial change. On the vertical dimension, greater decentralization of competences could be found in all cases where a reform took place. Decentralization is thus a main instrument of accommodation policies, a result in line with previous research on regional authority (Hooghe, Marks, and Schakel 2010). In addition, there seems to be no natural end to this tendency; rather, one decentralizing territorial change is followed by the next, while the party constellation mainly affects the speed of this dynamic.

On the horizontal dimension, we found changes in all three assumed directions (increase, decrease, and no change). Our comparative perspective on those cases suggests a distinction of two kinds of dynamics. One typical dynamic is the alteration between increase and decrease of jurisdictional heterogeneity while continuously decentralizing more competences. An increase is a result of bilateral negotiations between more empowered substates and the center; a decrease can be the result of either bilateral negotiations between less empowered substates and the center or unilateral decisions by the center to restore symmetry. This result underpins the distancing-catching up or resymmetrization pattern as previously described by Hombrado (2011). 
The second dominant dynamic is uniform decentralization without creating or reducing jurisdictional heterogeneity that results from either uni- or multilateral negotiations. A broad consensus is required in multilateral negotiations to reach an agreement. Alternatively, high political costs of failure, such as the inability to form a coalition-government in Belgium, raise the incentives to agree to a reform. Here, the split party system together with the required majorities in each linguistic group in parliament leads to symmetric package deals between the two large RegionsFlanders and Wallonia-and the two large Communities-Francophone and Flemish-while asymmetries were only introduced in the course of the regionalization process and with regard to the smaller entities of the BrusselsCapital Region and the German Community. NSWPs can play a role in pushing for further decentralization in the negotiations. But SWPs have greater power to promote symmetric changes in multilateral and unilateral negotiations, as diverging preferences of representatives of different substates and the center need to be moderated to reach a consensus.

When analyzing the role of independent variables, the picture becomes a bit fuzzier. We distinguished three aspects of parties' negotiation power: electoral threat of NSWP's, the participation in government of the initiating party, and congruence of governments between levels. Electoral threat of NSWP's (which are either in opposition or small coalition partners) nudging governing parties toward more decentralization-friendly positions was found in half of all cases, involving all countries, ${ }^{24}$ all negotiation modes and patterns 1, 2, and 3. Thus, NSWP's sometimes play a role, but no clear correlation to either negotiation modes or patterns of territorial change can be established. In all cases, the party or parties initiating the reform were also part of the government (coalition). ${ }^{25}$ Holding government is thus a far more important asset of negotiation power than electoral threat. From our limited set of empirical observations, it even looks like a necessary condition for initiating serious reform negotiations. Congruence as the third ingredient of negotiation power is irrelevant in the unilateral mode, and close to unattainable in multilateral negotiations. For the bilateral mode, however, it seems to be a relevant category. Of the six cases in bilateral mode, four were at least partially congruent and concluded negotiations successfully for the region while in one case (Plan Ibarettxe), the territorial reform failed under a condition of incongruence. Thus, in our empirically limited universe at least, congruence is a good predictor for subnational negotiation success in bilateral negotiations.

The second independent variable, negotiation mode, is strongly correlated to certain territorial dynamics, as outlined above: bilateral negotiations promote the distancing-catching up-pattern, while multilateral negotiations are helpful for uniform decentralization trends. This finding is in line with our expectations. Although it was mainly the aim of this article to investigate the role of negotiation mode in shaping the territorial power distribution, the empirical analysis also hints 
at reasons for the selection of a particular mode. Certainly, the negotiation mode is influenced by the constitutional or institutional structure of the respective country (see Bolleyer, Swenden, and Mcewen 2014). The regional statutes in the UK and Spain can be altered by legislative acts of the central parliament, thus encouraging bilateral negotiations between the regional and the central governments. Territorial renegotiations in Belgium usually take place in coalition negotiations for the federal government, which are-according to our definition, unilateral negotiations, as no substate actor is directly involved. In Canada, territorial renegotiations typically are multilateral intergovernmental bargains between elites or all federated entities resulting in laws or regulations below the constitutional level. Those constitutional or institutional provisions are not determinative, however, for the choice of negotiation mode. Negotiation modes may be provoked by institutional rules but the constellation of the actors is decisive for the interplay between mode, power, and reform result. In several cases, we observed alternations in the negotiation modes in comparison of cases within countries, such as a unilateral change in Spain or including new actors for ratification as with the referendum in Canada. Thus, while we can see a clear causal link between institutional structure, negotiation mode and territorial dynamic, the choice of negotiation mode is still open to strategic considerations of political actors. If, for example, substate actors in Spain or the UK initiated a multilateral negotiation process, it would very likely result in a far broader reform of the entire multilevel structure of the country, rather than just another round of the distancing-catching up-game.

In terms of interaction between negotiation power and negotiation mode, we can observe that the negotiation power of a party or coalition is moderated by the negotiation mode. Even if a party's negotiation power is strong, in multilateral negotiations it will be forced to accept a compromise reflecting a broader consensus. In bilateral negotiations, in contrast, negotiation power of the initiating party is enhanced and its preferences are reflected directly in the negotiation results. In particular, NSWP's which are typically weaker in terms of electoral support and less often involved in central governments, are thus well advised to pick a bilateral negotiation mode because this enhances their chances to realize their preferences. But also in unilateral negotiations, NSWP's have a chance to play a pivotal role if their votes are needed to meet a qualified majority.

Neither negotiation power nor negotiation mode is, however, suited to predict blocked reforms, as manifested in our pattern 5. Blocked reforms are not uncommon in multinational contexts in which contrasting visions regarding the rationale of the state and the appropriate power allocation exist. In our cases, blockades occurred when "external" actors, those that had not been directly involved in the negotiation process, were needed to ratify the negotiation result. The two-step negotiation process of regional statute reform in Spain opened up the possibility for statewide parties to block a reform proposal at the center. And in 
Canada, the multiple ratification hurdles can have destructive effects on every consensus previously reached in negotiations, thus demonstrating the fragility and temporality of consensus between different actors in multinational contexts.

\section{Conclusion}

This article made a first step to unravel the relation between party preferences and different dimensions of territorial change as a result of negotiation processes between representatives of central governments and substates. We proposed an actor-centered institutionalist explanation for the patterns of territorial change, focusing on preferences and negotiation power of parties as the main drivers in negotiation processes of territorial restructuring. Thereby, we avoided the narrow focus on NSWPs as drivers for decentralization and included statewide and NSWPs at the central and the substate levels as initiators of reform processes.

We extended our understanding of territorial change in three relevant ways: First, we operationalized territorial change in a two-dimensional space thereby paying more attention to horizontal differences between the substates. Second, we linked TPP with institutional aspects of the negotiation process. The distinction between uni-, bi-, and multilateral negotiations allowed us to take the multilevel character of negotiations more explicitly into account. In fact, the negotiation mode proved to account for relevant differences in the resulting territorial change. We could demonstrate that the negotiation mode affects the horizontal dimension of power allocation more than the vertical one. Including the negotiation mode allows us to better explain why substates without strong NSWPs are involved in asymmetric solutions; and why the existence of strong NSWPs does not necessarily lead to asymmetries in the allocation of power. The first scenario is linked to bilateral negotiations, while in the second, the pressure of NSWPs is moderated by a multilateral mode of negotiations and the preferences of SWPs eventually resulting in symmetric solutions. The choice of one or another negotiation mode thus influences a party's chance to realize its preferences in a distinct manner.

A third finding is that centralization seems to be not negotiable. We know of attempts by central governments, for example in Canada or in Spain, to foster a stronger economic union by centralizing competences in that field. Nevertheless, the outcomes of reform negotiations did not include a retransfer of powers to the center. We would expect that once a policy or competence is decentralized, central governments find other ways to achieve an increase in centralization.

Future research on territorial dynamics should investigate those options and their relation to formally negotiated decentralization. Also, the role of constitutional courts as external actor influencing the dynamics of negotiations or the power of substates remains to be explored. Links to negotiations on territorial change exist in several cases, but systematic connections have not yet been 
established. Finally, the allocation of power is closely related with financial resources. Another task for future research could be the extension of our model to the analysis of fiscal relations.

\section{Notes}

This work was supported by the Center of Excellence, EXC 16 "Cultural Foundations of Social Integration" funded by the German Research Foundation, grant number $757 / 11$. We would like to thank the three anonymous reviewers for their thoughtful comments and recommendations. The article benefited tremendously from their thorough reading and knowledge of the subject. All remaining errors are of course our responsibility.

1 The regional authority index (Marks, Hooghe, and Schakel 2008) captures both components, but explores power relations from the perspectives of the region only. As our focus lies on formal negotiation processes, we take both perspectives of central and substate levels into account. Furthermore, the demands of national communities are predominantly directed at gaining autonomy from the center and at reducing central encroachment. Finally, in these contexts coordination between the levels is established rather informally and with considerable time lag thereby escaping our focus of formal negotiation processes.

2 It may well be that change was attempted but was not successfully effectuated. In such a case, the ensuing pattern of territorial change is one of blocked change. Conceptually, "no change" represents a possible and realistic value of territorial change.

3 There is no uniform nomenclature for denoting specific party types: In the literature, references can be found to regionalist, non statewide, nationalist, or ethno nationalist parties in addition to statewide and mainstream parties. In this article, we focus on the distinction between statewide and non statewide parties. Since not all NSWP are nationalist, we prefer this term to characterize parties that differ in terms of their pervasiveness and electoral success across the territory.

4 Unilateral decisions of the federated entities are, of course, also possible. However, with regard to the allocation of power and rules of constitutional change, we expect that such decisions will only affect de facto asymmetries and the exercise of competences. Changes in de jure responsibilities between the levels of government will, therefore, not be possible without a certain involvement of the center.

5 We "measure" the values of the relevant variables not in a formal sense of assigning numerical values to empirical manifestations. Rather, we classify them verbally at an ordinal or categorical level (more or less, yes or no), thereby avoiding seeming exactitude which would not be matched by the fuzziness of reality.

6 Andalusia had been the first Spanish region to establish the same level of autonomy as the three so called historical nationalities (País Vasco, Galicia, and Cataluna) at the very beginning of the Spanish decentralization process and repeated this catching up quest during the last territorial reform wave.

7 Organic law 6/2006 (19.07.2006), BOE 172/2006 (20.07.2006). 
8 Scotland Act 2012, chapter 11, 01.05.2012.

9 Chambre des Représentants / Sénat (1992 1993); Projet de loi spéciale visant à achever la structure fédérale de l'état.

10 Loi spéciale portant transfert de diverses compétences aux régions et communautés (13.07.2001); Loi spéciale portant refinancement des communautés et extension des compétences fiscales des régions (13.07.2001).

11 The particularity of the party system in Belgium split along linguistic lines makes the classification of the negotiation mode more difficult as the negotiations always incorporate an intergroup aspect. They do not classify as bilateral negotiations as defined above since they do not take place between representatives of either the Flemish or the Walloon regional government and the center. However, negotiations in Belgium also differ from multilateral modes as representatives of regional governments are not included as such and regional parliaments have no role in the ratification process. We, therefore, chose to classify the negotiations in Belgium as "unilateral" as they take place at the federal level only with the involvement of the two chambers of the federal parliament. The split party system adds an intergroup element that is biased toward the two major groups but excludes representatives of the smaller entities of the federal system.

12 The party split in 2001, with the N VA representing the conservative wing of the nationalists. The leftist wing, reformed as Spirit, entered an electoral alliance with the Flemish Socialists (Sp.a.), but separated again in 2007. This group eventually fell into decline, with their last parliamentarian joining the Flemish Ecologists.

13 The 1987 Constitutional Accord, 03.07.1987 "The Meech Lake Accord."

14 Consensus Report on the Constitution Charlottetown Accord, 28.08.1992.

15 It is possible, though, that other less empowered substates remain at the same low competence level. Strictly speaking, those substate units that try to catch up with higher competence levels widen the distance to those less empowered units at the same time. Nonetheless, as the movement is aimed at reducing distance with the most empowered units, we classify this change as a decrease in asymmetry.

16 The territorial reforms of 1980 and 1988 in Belgium established jurisdictional asymmetry between the Regions of Flanders and Wallonia and the less empowered region of Brussels Capital. As these reforms were only creating the substate institutions, we did not include them in our sample. For our analysis, Belgium starts with this asymmetry between the Regions and symmetry is only eventually restored with the reform of 2012/13.

17 MAP (Ed.), Acuerdos Autonómicos de 28 de febrero de 1992 (1992); Organic Law 9/ 1992 (23.12.1992); BOE 308/1992 (24.12.1992).

18 Due to our criteria for case selection, these early reform processes are excluded from the analysis. The imminently preceding reforms had all resulted in symmetric changes to powers of federated entities. It was only in the most recent round of state reform that the early established asymmetries were abolished.

19 Accord institutionnel pour la sixième réforme de l'Etat. Un état fédéral plus efficace et des entités plus autonomes.

20 Organic law 2/2007 (19.03.2007); BOE 68/2007 (20.03.2007). 
21 Government of Wales Act 2006, chapter 32, 25.07.2006.

22 The most encompassing legal document containing envisaged changes of jurisdictions for Wales by the referendum is the "third draft Order: the 'National Assembly for Wales' (Legislative Competence) (Amendment of Schedule 7 to the Government of Wales Act 2006)," approved by the National Assembly of Wales on 9 November 2010.

23 El Mundo: Posiciones de los partidos ante el Plan Ibarretxe, http://www.elmundo/2005/ 01/13/espana/1105634554.html.

24 We found only one instance in Canada, where NSWP's apart from the PQ and party system characteristics in general play a minor role in territorial negotiations.

25 One exception is the Scotland Act 2012 reform, which was formally initiated by opposition parties, who had however the parliamentary majority and congruence with the central government. What is more, in the later stages of the negotiation, the governing party supported the reform. Interestingly, it seems to be irrelevant for the horizontal dimension of territorial change whether the parties initiating the reform are SWP's, regional branches of SWPs or NSWPs.

\section{References}

Amoretti, Ugo M. and Nancy Bermeo, eds. 2004. Federalism and territorial cleavages. Baltimore: John Hopkins University Press.

Bednar, Jenna. 2009. The Robust Federation. Principles of design. Cambridge: Cambridge University Press.

Bermeo, Nancy. 2002. The import of institutions. Journal of Democracy 13 (2): 96110.

Bezes, Philippe, and Salvador Parrado. 2013. Trajectories of administrative reform: institutions, timing and choices in France and Spain. West European Politics 36 (1): 2250.

Bolleyer, Nicole, Wilfried Swenden, and Nicola Mcewen. 2014. A theoretical perspective on multi level systems in Europe: Constitutional power and partisan conflict. Comparative European Politics 12 (4 5): 36783.

Bradbury, Jonathan, and James Mitchell. 2005. Devolution: between governance and territorial politics. Parliamentary Affairs 58 (2): 287302.

Broschek, Jorg. 2011. Conceptualizing and theorizing constitutional change in federal systems: insights from historical institutionalism. Regional \& Federal Studies 21 (4 5): 53959.

Cabeza, Laura, and Braulio Gomez Fortes. 2010. Referéndums sin ciudadanos. El caso del referendo para la reforma del Estatuto de Autonomía andaluz. Centro de Investigaciones Sociológicas 130: 1140.

Cairns, Alan C. 1988. Ottawa, The Provinces and Meech Lake. In Meech Lake and Canada. Perspectives from the West, ed. Roger Gibbins, 105 19. Edmonton, AB: Academic Printing \& Publishing.

Clement, Jan, Julie de Groote, Marcel De Visscher, Hans D’Hondt, Jan Van Crombrugge, and Christine Vanderveeren. 1994. Les accords de la Saint Michel. Bruxelles: Bruylant. 
Colino, César. 2008. The Spanish model of devolution and regional governance. Evolution, motivations, and effects on policy making. Policy \& Politics 36 (4): 57386.

De Winter, Lieven, Margarita Gómez Reino and Peter Lynch, eds. 2006. Autonomist parties in Europe: identity politics and the revival of the territorial cleavage. Barcelona: Institut de Ciències Politiques i Socials.

Delwit, Pascal, and Benoit Hellings. 2002. La nouvelle réforme de l'État: processus, contenu, méthode. Administration Publique 26 (2 3 4): 99106.

Detterbeck, Klaus. 2012. Multi Level party politics in western Europe. Houndsmills, Basingstoke: Palgrave Macmillan.

Elazar, Daniel J. 1987. Exploring federalism. Tuscaloosa: The University of Alabama Press.

Elias, Anwen, and Fillipo Tronconi. 2011. From protest to power: Autonomist parties in government. Party Politics 17 (4): 50524.

Elster, Jon. 1998. Deliberation and constitution making. In Deliberative democracy, ed. Jon Elster, 97 122. Cambridge, New York: Cambridge University Press.

Erk, Jan, and Edward Koning. 2010. New structuralism and institutional change: federalism between centralization and decentralization. Comparative Political Studies 43 (3): 35378 .

Filippov, Mikhail, Peter C. Ordeshook, and Olga Shvetsova. 2004. Designing federalism. A theory of self sustainable federal institutions. Cambridge: Cambridge University Press.

Gagnon, Alain G. and James Tully, eds. 2001. Multinational democracies. Cambridge: Cambridge University Press.

Gerber, Elisabeth, and Ken Kollman. 2004. Introduction authority migration: defining an emerging research agenda. PS: Political Science and Politics 37 (3): 397401.

Grau, Mireia. 2011. Self government reforms and public support for Spain's territorial model. Revista d'Estudis Autonòmics i Federals no. 13:186 214.

Hombrado, Angustias. 2011. Learning to catch the wave? Regional demands for constitutional change in contexts of asymmetrical arrangements. Regional \& Federal Studies 21 (4 5): 479501.

Hooghe, Liesbet, Gary Marks, and Arjan H. Schakel. 2010. The rise of regional authority: a comparative study of 42 democracies (1950 2006). London: Routledge.

Jacques, Charles Xavier, and Charles Boromée. 2001. La Conférence intergouvernementale et interparlementaire du renouveau institutionnel. Courrier hebdomadaire. Bruxelles: CRISP.

Keating, Michael. 2001. Plurinational democracy. Stateless nations in a post sovereignty era. Oxford: Oxford University Press.

Laforest, Guy. 1991. L'esprit de (1982). In Le Québec et la Restructuration du Canada 1980 1992. Enjeux et perspectives, ed. Louis Balthazar, Guy Laforest and Vincent Lemieux, 147 63. Saint Laurent, QC: Les éditions du Septentrion.

Lecours, André. 2004. Moreno's multiple ethnoterritorial concurrence model: A re formulation. Regional \& Federal Studies 14 (1): 6688. 
Lentzen, Evelyne, and Pierre Blaise. 1993. La mise en œuvre des priorités du gouvernement Dehaene I. La réforme des institutions. Courrier hebdomadaire. Bruxelles: CRISP.

Maddens, Bart, and Liselotte Libbrecht. 2009. How statewide parties cope with the regionalist issue: the case of Spain; a directional approach. In Territorial Party Politics in Western Europe, ed. Wilfried Swenden and Bart Maddens, 204 28. New York: Palgrave Macmillan.

Marks, Gary, Liesbet Hooghe, and Arjan H. Schakel. 2008. Measuring regional authority. Regional and Federal Studies 18 (2 3): 11121.

Massetti, Emanuele, and Arjan H. Schakel. 2013a. Between autonomy and secession: decentralization and regionalist party ideological radicalism. Party Politics (online first): advanced access.

. 2013b. Ideology matters: Why decentralisation has a differentiated effect on regionalist parties' fortunes in Western democracies. European Journal of Political Research 52 (6): 797821.

McLean, Iain, Jim Gallagher, and Guy Lodge. 2013. Scotland's choices. The referendum and what happens afterwards. Edinburgh: Edinburgh University Press.

Meguid, Bonnie M. 2005. Competition between unequals: the role of mainstream party strategy in niche party success. American Political Science Review 99 (3): 34759.

Milne, David A. 1988. Much Ado About Meech. In Canada: The State of the Federation 1987 1988, ed. Peter M. Leslie and Ronald L. Watts, 97 115. Kingston, Ontario: Institute of Intergovernmental Relations, Queen's University.

Montero, Alfred P. 2005. The politics of decentralization in a centralized party system. The case of democratic Spain. Comparative Politics 38 (1): 6382.

Petersohn, Bettina. 2011. Konfliktakkommodierung bis zur Selbstaufgabe? Stabilitat und Dynamik der Verfassungsentwicklung in Belgien. Politische Vierteljahresschrift 52 (2): 195219.

Russell, Peter H. 2004. Constitutional Odyssey. Can Canadians become a sovereign people? Toronto: University of Toronto Press.

Scharpf, Fritz W. 1997. Games real actors play: actor centered institutionalism in policy research. Boulder: Westview Press.

.2000. Interaktionsformen: Akteurszentrierter Institutionalismus in der Politikforschung. Wiesbaden: VS Verlag fur Sozialwissenschaften.

Simeon, Richard. 1972. Federal provincial diplomacy: the making of recent policy in canada. Toronto: University of Toronto Press.

Sorens, Jason. 2009. The partisan logic of decentralization in Europe. Regional and Federal Studies 19 (2): 25572.

Swenden, Wilfried, and Bart Maddens. 2009a. Introduction. Territorial party politics in western Europe: A framework for analysis. In Territorial Party Politics in Western Europe, ed. Wilfried Swenden and Bart Maddens, 1 30. New York: Palgrave Macmillan. 
Swenden, Wilfried and Bart Maddens, eds. 2009b. Territorial party politics in western Europe. New York: Palgrave Macmillan.

Thorlakson, Lori. 2009. Patterns of Party Integration, Influence and Autonomy in Seven Federations. Party Politics 15 (2): 157177.

Toubeau, Simon, and Emanuele Massetti. 2013. The party politics of territorial reforms in Europe. West European Politics 36 (2): 297316.

Toubeau, Simon, and Markus Wagner. 2015. Explaining party positions on decentralization. British Journal of Political Science 45 (1): 97119.

Treisman, Daniel. 2007. The architecture of government: rethinking political decentralization. New York: Cambridge University Press.

Trench, Alan. 2008. Finding a Voive for Wales: Assessing three phases of constitutional development in Wales. In ECPR Joint Sessions of Workshops. Université de Rennes II.

Watts, Ronald. 1999. The theoretical and practical implications of asymmetrical federalism. In Accommodating Diversity: Asymmetry in Federal States, ed. Robert Agranoff, 2442. Baden Baden: Nomos Verlagsgesellschaft.

Whitaker, Reg. 1993. The dog that never barked: who killed asymmetrical federalism? In The Charlottetown Accord, the Referendum and the Future of Canada, ed. Kenneth McRoberts and Patrick J. Monahan, 107 114. Toronto: Toronto University Press.

Wyn Jones, Richard, and Roger Scully. 2012. Wales says Yes: Welsh devolution and the 2011 referendum. Cardiff: University of Wales Press. 